\title{
Measuring the Importance of Stemming Radicalism In the Decentralization Era of Democracy
}

\author{
ENDANG SUPRIADI \\ Fakultas Ilmu Sosial dan IImu Politik, UIN Walisongo Semarang \\ email: endang.supriadi@walisongo.ac.id
}

\begin{abstract}
This article is based on studies conducted to describe the stemming of radicalism in the era of democratic decentralization. The author has a thesis that the acceptance of radicalism narration occurred gradually. In the early stages of accepting the narrative, people begin to realize about the world's disaster and the prevailing system in society. They then withdraw from extrovert society by establishing a clear distinction between "us" and "them". The differences of identity begin to unfold along with denial of differences based on religious sentiments. An antidote to radicalization is necessary: deradicalization. Radicalism is not then present without being preceded by an intolerant attitude which then turns to acts of terrorism. When an individual commits an act of terror, it is indirectly past the stage before the individual commits the terror: intolerant and radicalism. In this era of decentralization, democracy starts the freedom of expression for every citizen, including criticizing government policies without fear of repressive actions from the state. Along with the strengthening of democratic decentralization policy, the dynamics of radical religious group movements also decentralized.
\end{abstract}

Keywords: Radicalism, Deradicalization, Democracy

\section{Introduction}

Is the democratization process that has been rolling since 1998 until now a blessing or a curse? The answer to this question can certainly vary depending on what perspective we use, whether it is pessimistic or optimistic. It has been more than 19 years of democratization running in the Republic of Indonesia which it would absolutely result in valuable experiences both in a positive and negative. The process of democratization has brought significant changes to the life of Indonesian people in term of social, political, economic, and religious. Civil liberties and rights are increasingly assured both in the behavior and institutions of democracy.

On specific historical background, the process of democratization that we see as a new stage resulted from the reversal of authoritarianism. Furthermore, since democracy comes as a result of political dynamic, it is often identified or equated as politics. Here, people generally recognize politics as an atmosphere of democracy. It is perceived as a mental state where public can express their freedom optimally which then give rise to the forms of political antagonism. Democracy basically has similar things with authoritarianism and both refer to the order or the way of government. The difference between them is the issue of who fills the order.

Democracy presupposes the absence of claims to fill the order permanently, while authoritarianism and the like claim to fill the complete, full, and permanent order. Democracy is presented as a mechanism and procedure for not doing anything and leaving the order as emptiness. As with reforms, democracy is a form of politics that has been embodied and has standards that can be objectively verified. Democracy is needed as a unit that then becomes part of the whole population of democracy. The presence of democracy has an impact on the change of existing order whether social, political, economic, and even religious.

Changes that occurred in postreformation, if it is examined more deeply, also raises its own problems with the emergence of religious groups that often put forward the ways of violence, such as

Received: January 29, 2017, Revision: January 11, 2018, Accepted: December 27, 2018

Print ISSN: 0215-8175; Online ISSN: 2303-2499. DOI: http://dx.doi.org/10.29313/mimbar.v34i2.3451.292-300

Accredited B based on the decree No.040/P/2014, valid on February, 18, 2014 until February, 18, 2019. Indexed by DOAJ, Sinta, IPI. 
the Islamic Defenders Front (FPI in Jakarta), Anti-Apostasy Movement and Disobedience (GAPAS in Cirebon), The Anti-Apostasy Movement and Cults (GAMAS in Cirebon), the Anti-Apostasy Movement Alliance (AGAP in Cirebon), the Islamic Reform Movement (GARIS in Cirebon), the Nahi Mungkar Community Alliance (Al Mannar in Cirebon), and any other extremist organizations (interview with Rojikoh, 12 September 2017). Under the pretext of representing the aspirations and interests of Muslims, they consider their actions to be true, even though their substance is contrary to the constitution. Some cases involving those groups are as follow: rejection of the construction of houses of worship for non-muslims, denial of church establishment, assault and dissolution of al-Magfurullah Klayan-Gunung Jati Cirebon community and halal bihalal (gathering) event of transvestites.

Seeing the cases above, the constitution of Indonesia clearly guarantees the independence of every citizen to become a leader or to have and implement their faith without any pressure from any party. Strictly speaking, if we refer to Pancasila and the 1945 Constitution, it is clear that Indonesia is not a religious state. Although religion is the spirit in life of the nation and state in Indonesia, it does not mean that the law of a particular religion (e.g. Islam) can serve as the basis for national law if in practice it discriminates other groups.

The inclusiveness of political freedom and democratization after the fall of New Order regime not only provided room for the emergence of various expressions built on primordial sentiments and identities, but also paved the way for the expansion of radicalism. This freedom at least has been used by radical groups to be more active in responding to the problems of national and state life. The intensity is increased in plain view with various variants of form and issue (Nurcholis, 2011: 150). The difficulty of early detection of time and place of the occurrence of terrorist acts is increasingly posing a real threat to Indonesia (Ruth, 2011: 6).

According to the thoughts of Crenshaw (2005), the acts of terror in Indonesia that counted since the Bali Bombing I are a new form of terrorism (new terrorism). Crenshaw further explained that new terrorism is an act of terror that still adheres to the same paradigm of terrorism in the past, but in a more different way along with the times.
Different ways here are viewed from the modus operandi of terrorists in committing acts of terrorism (Crenshaw, 2005 in Golose, 2010:9).

The area of Tiga Cirebon or Ciayumajakuning (Cirebon, Indramayu, Majalengka, and Kuningan), for example, in recent decades has become the focus of many parties. In the last 17 years, cases of violence in the name of religion happened everywhere which can be seen from various activities carried out by radical religious group movements. In Tiga Cirebon areas, the occurrence of such cases were carried out by radical religious groups/ organizations such as the Anti-Immoral Movement and Deviant Sect (GAMAS) and Anti-Apostasy and disobedience Movement (GAPAS), and others in Cirebon. These groups, at the beginning of their establishment, were very vociferous in voicing the implementation of Islamic law in Cirebon and the surrounding areas. Besides actively conducting raids on various form of behaviors which considered disobedience, GAMAS and GAPAS are also involved in intolerant acts committed in the areas of Tiga Cirebon.

Various acts of terror and violence perpetrated by GAMAS and GAPAS or the like in Cirebon and surrounding areas, if left unchecked would be a threat to both the rule of law and the continuity of democracy in Indonesia. These groups seem to always come up with variety of shapes, actions, and movements. For that reason, it is important to know why the group that at the beginning of its establishment was very keen on religious issues then shifted toward "intolerance" and control areas of Tiga Cirebon? Why does this group able to survive, even more, influential in line with the development of democracy in Indonesia? A program of deradicalization is needed to stem and eradicate radicalism in the era of democratic decentralization.

\section{Research Methods}

This article is written based on research using qualitative method to see the importance of stemming radicalism in the era of democratic decentralization. GAMAS and GAPAS are among the few groups that are known to be very vocal as radical voices for the implementation of Islamic law in areas of Tiga Cirebon and active in conducting raids on acts considered disobedience. To produce comprehensive data, the authors made direct observations and indepth interviews 
with 5 informants considered relevant, knew the actions, and even had contact with the group's activities. They are local media crews, academics, local politicians, youth activists, and business actors. To enrich the primary data, the authors also conduct literature review from various sources, such as books, magazines, newspapers, and other sources related to the research subject.

\section{Understanding the Essence of the Meaning of Radicalism}

Many people understand the concept and meaning of radicalism as part of a strategy for terrorists, and there are also stages of one's intolerant attitude which will then turns into radicalism. When we look more closely at the word 'radical', it is a philosophical term of radix means rooted, profound, comprehensive, and has a solid foundation. Thinking radically means having a profound, deep-rooted, sharp, and critical mind. According to Zuly Qodir, radicalism is an idea that requires change and change of system in society to its roots (Qodir, 2014: 116).

Every human should actually think radically, think sharply, and think deeply. As well as in religious matters, people should be radical, kaffah (thoroughly), comprehensive, universal, and holistic; if someone is not radically religious then he cannot reach the peak of faith. Radicalism is a process for realizing a student who learns sharply and deeply (Idris, 2016: 30). The terms radical and radicalization are still very common and there is no meaning associated with religious doctrine. But the image of radical that understood by society has been distorted and shifted the meaning into more narrow, discriminating, and full of suspicion for certain parties.

The term radicalism is an ideology that searching and making changes gradually, and the process is fast, using violence, anarchism, misleading in the name of religion, wrapping anarchist behavior with religious clothing, and packing crime with religious narratives. As a result, common people easily support and participate to encourage the action of anarchism. Anarchism is wrapped in war; murder is wrapped in jihad, death in anarchist action is immediately considered as a syahid/ syuhada (martyred).

Radicalism is one of the four spectrums of Islamism, often referred to as political
Islam, conceptualized primarily not as a symptom of religion, but rather a sociopolitical phenomenon involving a group of Muslim individuals who are actively engaged in a movement based on a particular ideology they believe in (Hasan, 2010: 28-51). Islamism is a religious-political expression that spans four major spectrums of militancy, radicalism, extremism, and terrorism. These four things sequentially indicate the gradation of influencing power of Islamism on a person.

The concept of militancy refers to intolerant thoughts, views, and actions that seek and encourage change by the distance in open society. There is sincerity, firmness, and commitment to certain beliefs, thoughts, attitudes, and principles built into a militant. This principle is rooted in suspicion and hatred against those who have no view or understanding toward them. The most important consequence of militancy is a commitment to abstain from and neglect other influences, which is often defined as "kafir". Intolerance becomes a keyword in militancy (Hasan, 2010: 28-51).

Militancy can develop into radicalism, which is a variant in Islamism that demands radical change in political system or society. Radicalism has a central vision of the Islamic political order that rejects the legitimacy of modern sovereign nations and seeks to establish a pan-Islamic government or revitalize the Caliphate. An activity or thinking is categorized as radical if it rejects the legitimacy of the contemporary nationstate system and seeks to replace it with a completely new system of politics and government based on syari 'ah (Qodir, 2002: 120).

Inside radicalism intends a revolutionary spirit that requires a thorough change of system but does not require instantaneous action and the use of violent methods. Radicalism is more about the basic attitude that requires a thorough change of the existing system and order, and therefore, can be more patient with the expected change. If the desire to change the system is not found, the radicals do not frequently legitimize the use of violence to realize their Islamic vision which results in extremism.

Extremism emphasizes the path of violence as the primary method and even the only one considered legitimate to reach political changes. Extremism is always revolutionary because it deals with the methods of knocking down and breaking down 
the old system and build upon the ruins of an entirely new system. The change is expected to happen quickly and instantly and through the path of violence. Unlike radicalism, extremism shows impatience in waiting the changes by choosing violent ways (interview with Marzuki Rais, 2017).

Violence in the name of religion is often shown by radical groups. There is a term of religious radicalism which is improperly used as opposed to pure logic and loaded with distorted meanings because radicalism is an ideology of anarchist religion, while all religions in this world do not have anarchist doctrine, corrupting and annexing the official territory of a country. All humans crave a peaceful, calm, prosperous and comfortable atmosphere; even humans who have no religion or no religious beliefs crave peace. Radicalism in the name of religion is happening a lot today and has become a religious social phenomenon in the world.

In sociological perspective, religious radicalism will be related to the development of contemporary ideologies. Sociology will certainly observe the phenomenon of radicalism from a different perspective of theological perspective, as well as historical and political economy. Sociology will provide a description of radicalism phenomenon from aspects of social background, the actors, supporters, and capitalists behind all the radical movements. In fact, sociology will also be extended to the study of radical organizations that became the ideological base.

\section{Examining the Influential Social Condition: A Root of Radicalism}

The development of social condition is a factor in the emergence of radical attitudes that reside in young people along with other groups since the social dimension faced is considered as a system that must be changed and opposed collectively and not individually. Nevertheless, there is still a group of people and some individuals who understand jihad as a resistance movement using weapons and death as the last resort of the struggle.

Sociological perspective places young people as agents of social change. It can be said there are some key agendas which mark the discourse of youth: first, the science debate against destiny triggered by myth and scientific knowledge; second, the debate of education and nature as part of biological trigger of youth with cultural phenomena; third, the debate of older generation and social class leading to a debate on social class position between the old and the young in society; fourth, debate between agencies and structures due to the contradictions between the roles of social structure and agency as a factor of change expected to bring about a change; fifth, the debate between changes in social opponent structures occurred in society.

By viewing the space of youth debate, placing young people as an important part of the discussion of radicalism (including religious radicalism) becomes something that need to be done clearly and adequately. There are several factors causing the emergence of religious radicalism among young people. First, mental health problem (Cullough and Smith, 2003: 125) which exists in young people with a very vulnerable position. It makes them easily experience mental shock caused by various factors in life. Second, it is the lame economic factors. In the language of economics, sociologists create social grievances (social turmoil and anxiety) over a society that will abundance the economy. Third, socio-political conditions influence the change of behavior and the form of religious organization. Peter Beyer, this centuryrenowned sociologist explains that now and in the future due to changes in world political policy, as part of globalization politics, the changes will heal in the pattern of religious attitudes and religious organization.

Fourth, it is the religious commitment to religious understanding. In the midst of many serious problems affecting this nation, the question of certainty of people and groups in life is a demand that is almost always there. Religion cannot be seen in the perspective of profane and sacred. All religious dimensions are regarded as sacred. There is nothing profane in religion; therefore, the support of understanding the sacred always gets fairly rapid following in the troubled society. There are many reasons why people want certainty in life. The uncertainty of life then ends with a shortcut looking for certainty in religion.

Based on the above explanation, we become aware of why there are groups of people willing to die for his group, willing to die as martyr for a marginalized group, a group willing to die together by toxic gas or Molotov bombs for a belief which is believed to be a religious commitment. This is the most representative expression of the jihadists who never hesitate to commit acts of violence and 
terror over conditions around him (Kafid, 2016: 57-79). This is where the youth are often targeted by jihadists who interpret jihad as opposed to violence and physical warfare. Young people can be tempted to religious commitment which constructed as an advocate of God's justice on earth and who defends it is a religious hero who will get a noble place in the sight of God.

\section{Cirebon: Part of the Red Zone of Religious Radicalism.}

Cirebon mentioned here is not only a municipality of Cirebon but covers areas of Cirebon, Indramayu, Majalengka and Kuningan (ciayumajakuning). Along those regions, groups and certain streams flourished from socialist, nationalist, to Islamist, see the diagram 1. No wonder those three areas of Cirebon are said to be a red zone of religious radicalism. Recent intolerant cases have provoked anger of public.

\section{Diagram 1}

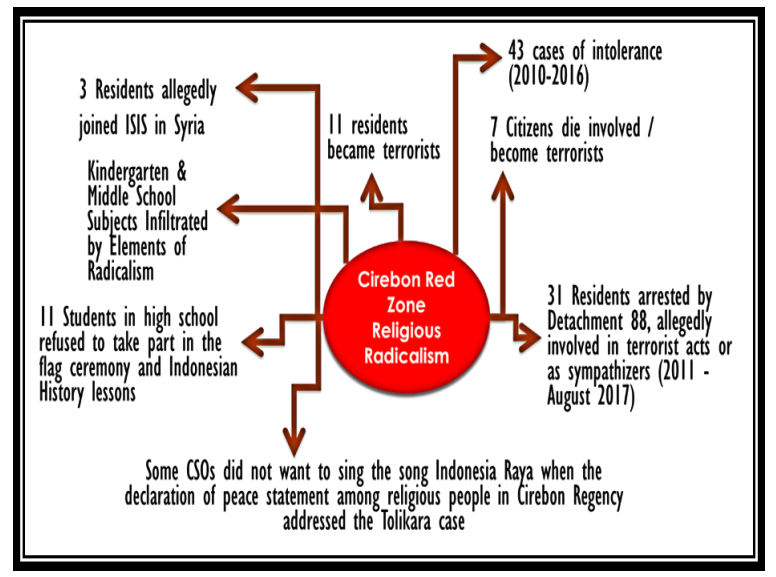

Source: Interview and local Cirebon media

Since reformation, religious radicalism in Cirebon region seems to continue to form a social relationship within public spotlight. A number of Islamic religious groups are allegedly active in various social actions, such as jihad movement, Islamic Shari'a enforcement movement, demands for legitimating the Miras regulation, the closing of disco pubs and nightclubs, the anti-American movement, the Islamic State of Indonesia (NII), even the support movement of Islam State of Iraq and Syria (ISIS) (Zulkarnain and Septayuda, 2016). Thus, Cirebon is seen by some as a fertile ground for the nursery of radical Islamic group movement. Their activities are closely related to some international Islamic organizations, such as Jamaah Islamiyah (JI), Jamaah Anshoru Tauhid (JAT), and other radical Islamic religious movements (interview with Rojiqoh, 12 September 2017).

In terms of religion and ethnicity, Cirebon has a high level of plurality. Although religious symbols such as places of worship look so prominent, there are culturally a group of people called abangan (Muslim or other) that are still dominating. In addition to the celebrations of religious festivals that look so festive, various rituals of belief in local culture still continue to be carried out solemnly. Such conditions have allegedly induced the emergence of various movements under the pretext of purification of religion, even able to ignite social conflict.

The government system during centralistic-militaristic of New Order era was quite successful in suppressing various potentials of radical religious movements and social conflicts in Cirebon. However, it does not mean that those movements and conflicts really disappear. Although Abu Bakar Ba' asyir and Abdullah Sungkar (considered as the most vocal figures in opposing New Order's policy which incompatible with Islamic Shari'a teachings) secluded themselves to Malaysia (Purwawidada, 2014: 35), they were still able to control their group in Cirebon from the distance. Evidently, when the reform movement in 1998 succeeded in overthrowing Suharto regime, the two went back to Indonesia and reopened the network to make a move.

\section{Portrait of Religious Radicalism in Cirebon}

The collapse of New Order's authoritarian regime triggered the rise of various radical religious movements in Indonesian, particularly in the Tiga Cirebon areas. The spirit of nationalism from reform was successfully exploited by various radical religious groups to re-emerge themselves with variant of names and forms. There are at least 11 groups appearing in Cirebon after the New Order: Jamaah Islamiyah (JI), Laskar Umat Islam (FUI), Nahi Mungkar Community Alliance (Al-Manar), Al-Irsyad, Jamaah Anshorut Tauhid (JAT), Anti-Maksiat (anti-immoral) Movement (GAMAS), Alliance of Anti-Apostasy Movement (AGAP), Majelis Mujahidin Indonesia (MMI), Anti-Apostasy Movement and Cults (GAPAS), Islamic Reform 
Movement (GARIS), Forum of City Guardian Gathering (FOSKAWAL), (interview with Marzuki Rais, 15 September 2017).

Radical groups viewed that the mainstream Islamic forces, especially NU and Muhammadiyah, were less quickly in responding to challenges perceived as threaten to the existence of Muslims in Indonesia. Since their form of thoughts and movements are fundamentalist-radical and allergic to various types of discourse that come from the "West", then the mindset developed is Islam versus West. However, not all radically categorized groups always use violent means to achieve their ideological goals. There are some groups that easily disbelieve other groups when they are deemed incompatible, even in certain contexts to justify all means, including by using violence to realize their ideological goals.

The movements not only focus on the group they call the West or their cronies but also to fellow Muslims who are considered liberal and support Western idea. All radical groups in Cirebon region have an intersection of interests in the framework of Islamic Shari'a enforcement struggle. They have similar concern for the state to pay attention and apply the Shari'a of Islam more seriously, as well as the Muslim community.

Their understanding is at least based on three main factors namely theological, demographic, and socio-political (Baidhawy, 2010: 659-682). Theologically, Islam is a religion that offers guidance and solutions to all aspects of social life, cultural, economic, political, etc., so that all Muslims must base all areas of life on the values and teachings of Islam as included in the Islamic Shari'a.

Demographically, since Muslims are the majority of population in Indonesia, Islam is believed to function as a socio-cultural and political legitimacy, the state base, or at least to recognize Shari'a of Islam as the core matter or an integral part of the constitution. And socio-politically, the secular law will not lead to socio-cultural, economic, legal, and political reforms for Muslims.

The enforcement of Islamic Shari'ah became a central issue shared by various radical religious groups in Cirebon, but each group tended to have different ways to fight for the issue. Anti-Apostasy and Disobedience Movement (GAPAS) as one of the radical religious groups in Cirebon is one of the groups known to be very active in many actions, such as sweeping against foreign citizens in Cirebon and raiding various places considered immoral (interview with Devida, 15 September 2017). Even in performing their actions, GAPAS had several times clashed with other groups.

\section{Socializing the Deradicalization Program to Stem Radicalism.}

Until now, the dynamic of Indonesian society life still has not shown a stable condition after the reform era. The transition from the authoritarian regime to constitutional democracy has been going on for quite a while. However, it has not been accelerated to the next stage of consolidation of democracy. In fact, the stage of democratic consolidation determines whether efforts to build a system of constitutional democratization as a goal of reform can be realized or not. One of the causes comes from internal and external factors that have been put the nation in transition stage for such a long time.

The internal factors aforementioned include ethnic heterogeneity, religion, culture, and economic and social inequality which increasingly enlarge the potential for radical ideologies. This unseen threat poses a great danger to the survival of Indonesian people, and not to mention the new ideologies that seems to be easier to develop and grow compared to the New Order era. The price of freedom of politics and democracy is expensive in Indonesia after seeing a series of cases of terrorism occurred. The increasing number of terrorism cases since the beginning of the reform shows the lack of responsiveness of the security forces to recognize or acknowledge the threats. Those threats make a radical ideology capable of moving civilians into perpetrators of terrors. Civilians who are supposed to be a component of defense support have the potential to become actors of radicalism that disturb the integrity of Indonesian nation (Hikam, 2016: 32).

As for the external side, the main factor is the national security that still faces the threat of re-emergence and rampant actions of anti-NKRI (the unitary state of the Republic of Indonesia) groups. The openness of political life is exploited by such groups to bring their new ideologies that endanger the national integrity. The groups had previously been below the surface or even positioned outside Indonesia, but they were able to get in due to the weak of national security and 
did their cruel actions of terrors.

The recent terrorism in Indonesia has ideological, historical, and political linkage and is part of the dynamic environment of global and regional level. Despite the fact that recent acts of terrorism occurring in various regions were mostly done by Indonesians and few abroad actors, it is undeniable that the current acts of terrorism is a combination of domestic actors and transnational networks.

In the face of radical movements, radical views and ideologies need to be understood because they involve understanding and rationale. Countering terrorism through a soft approach requires a comprehensive foundation of Pancasila. Pancasila is believed to be one of the soft approaches aligned with the realization of a deradicalization program (Hikam, 2016: 45). In addition, Pancasila serves as a national philosophy of life and national ideology with the concepts and vision that can be translated into the life of Indonesian society. There are five precepts that comprehensively describe the meaning of state life that can be used as a foundation against the threat of radical ideology.

Many countries have expressed their appreciation for Indonesia for its soft and hard approach to combat terrorism, the enforcement efforts carried out by security apparatus, the Special Anti-Terrorism Detachment 88 police unit of Republic of Indonesia, the Task Force of Indonesian National Army, the anti-terror task force of the Attorney General's Office Indonesia, and other law enforcement agencies. All terrorist acts can be dealt with by bringing the alleged perpetrators of terror before justice until they get legal verdicts and arrest them in jail.

But it should be understood that terrorism is not a common crime; it is an extraordinary crime against humanity, a transnational crime against state ideology. 'One falls and a thousand spring up' seems to be the spirit of militancy possessed by terrorists who shrewdly packed crime with language and religious symbols that ordinary people would judged their acts as holy acts or the jihad effort implied in Islam. Whereas, Islam and other religions have no radical anarchist ideology moreover suicide bombings.

The success of law enforcement officers to act against terrorists is not followed by efforts to prevent the emergence of crimes against humanity. The planting of hatred and hateful speech still continues to spread in society; brainwashing efforts are still intensively occurred among younger generation, especially the educated ones in high school.

An effort to offset the success of law enforcement officers is by cracking down on suspected terrorists. The government through BNPT (The National Agency for Combating Terrorism) conducts a deradicalization or coaching program to the affected community which ensnared by persuasion of ISIS recruiters, or the invitation and temptation of the anarchist radical network which continues to be waged either by conventional means of invitation to join radical groups anarchist from house to house or a more sophisticated and widely used way of social media.

Deradicalization has three dimensions (Idris, 2016: 36-37): first, deradicalization as a strategy; second, deradicalization as a program; and third, deradicalization as an institution. Many efforts have been formulated, planned, implemented, monitored, and evaluated in the running of deradicalization. Unfortunately, they were not maximally implemented, not yet intact, and in particular, there was the absence of institutional synergies in implementing deradicalization as a strategy or as a comprehensive and holistic program.

Then the question arises: why did the term and deradicalization programs appear? First, it appeared because of the increased proliferation of radical actions in the name of religion which then went up to terrorist class and destroyed lives. It also devastated the order and demands of religion, society, and state. Based on that, deradicalization is an effort to reduce the ideology of radical salafi jihadi and impose the will toward a radical ideology that is critically accommodative and acculturative. Deradicalization is also the antithesis of radicalization that makes religion an ideology in the struggle and fulfillment of its mission even though it is carried out with a very shallow, limited, and rigid ideology.

Secondly, a deradicalization program promoted by the government through the National Agency for Combating Terrorism is an attempt to engage radical society, especially terrorist prisoners, former terrorist prisoners, their families and networks in order to return them to the right path based on religious, moral, and ethical rules with the essence of teaching all religions the value of diversity, not in a hated way on the one hand and behave 
in the name of religion on the other. Another essence of the program is to return them to be a true Indonesian citizen based on Pancasila and the 1945 Constitution in the territory of NKRI under the principle of unity in diversity of Bhineka Tunggal Ika (Idris, 2016: 46).

Deradicalization is a strategy based on a conceptual understanding to deal with the problem of terrorism. This concept reflects a need for change in counterterrorism. The previous strategy was strongly dominated by hard power into a synergistic balance with soft power.

The goal of deradicalization is for reorientation, as conceptualized by Golose (2010), namely that disconnection is social and cognitive changes in the sense of abandoning shared social norms, values, attitudes, and aspirations in a tentative manner the individual concerned is still a member of a terrorist network (Golose, 2010: 82).

The deradicalization program implemented by the government over the past few years has yielded concrete results. These achievements can be used to complement and strengthen counterterrorism efforts in Indonesia, and even contribute to a wider understanding of Indonesian civil society. Approaches of personal, closed, and adapted to the culture of terrorist networks are useful for understanding the root causes of terrorism, particularly regarding people's motivation to join, support, and sympathize with terrorist ideologies and groups such as Jamaah Islamiyah.

Personal approach will give special nuances that cannot be known by another approach. Deradicalization with a personal approach also has other advantage, that is, to understand directly and closely the problems faced by the target. This will help in determining what tactics can be used to make members of a terrorist group want to work together, leave the group, or stop hating groups that are considered enemies (Karnavian, 2011: 5-7). Due to variations in one's motives to join radical groups, attempts to change their thinking and behavior will be effective if officials are aware of issues that concern their personal interests.

A deep understanding of their personal issues will make a very significant contribution to changing the views and behavior of the radical group. In addition, the deradicalization program involves not only police but also broader stakeholders. In the context of today's global and regional and national developments, the role of Indonesian civil society is increasingly recognized and real, especially with the increasing role of what is known as non-state actors who could have a power that can complete the state power of (Muladi, 2011: 3). Modern Indonesian civil society starts to grow along with the emergence of independent organizations and movements in colonial society when the process of industrialization is introduced. The seeds of modern Indonesian civil society have also existed and can be found in cultural traditions with the characteristics of independence, self-sufficiency, and volunteerism.

The implications of deradicalization program on nation's ideological resilience from the view of terrorism can be seen through the analysis of various aspects. This is because the deradicalization program is one of the sub-sets of counter-terrorism in Indonesia that has not been held long. The results of analysis raised issues that must be solved to strengthen the ideology and national resilience.

\section{Conclusion}

The inclusiveness of political freedom and democratization after the fall of the New Order regime was not only provided room for the emergence of various expressions built on primordial sentiments and identities, but also paved the way for the expansion of radicalism. In line with the ongoing consolidation of democracy which characterized by the role of the state for the sake of civil order through deradicalization programs, the law apparatus captures, neutralizes, and tames members of the radical group until they significantly weakening the network of radicalism.

Organizational network radicalism is already weakened so far. However, such success does not mean the end of the threat of radicalism in Indonesia. For example, recently in Cirebon there was a rampant terror action started with intolerant-radical society attitude to terror activities. In the era of democratic decentralization, the role of all the people is needed and to stem radicalism there is should be a deradicalization program that includes all elements of both government and civil society using the approach of soft and hard power. The role of non-state actors (Indonesian civil society) in the 21st century is getting 
stronger and more positive in contributing to the process of de radicalization.

The role of civil society in the era of democratization is needed in counteracting radicalism in Indonesia.

\section{References}

Baidhawy, Z. (2010). "Dinamika Radikalisme dan Konflik Bersentimen Keagamaan di Surakarta." Banjarmasin: Anual Conference on Islamic Studies (ACIS) ke-10.

Cullough, Michael Mc.dan Smith, T. (2003). Religion and Health: Depressive Symtoms and Morality as Case Studies. Cambridge: Cambridge University Press.

Golose, P., R. (2010). Deradikalisasi Terorisme: Humanis, Soul Approch dan Menyentuh Akar Rumput, Jakarta: YPKIK.

Hasan, N. (2010). "Ideologi, Identitas dan Ekonomi Politik Kekerasan: Mencari Model Solusi Mengatasi Ancaman Radikalisme dan Terorisme di Indonesia". Prisma, Vol. 20, 28-51.

Hikam, M., A.S. (2016). Deradikalisasi: Peran Masyarakat Sipil Indonesia Membendung Radikalisme, Jakarta: Kompas.

Idris, I. (2016). Membumikan Deradikalisasi: Soft Approch Model Pembinaan Terorisme dari Hulu ke Hilir secara Berkesinambungan, Jakarta: Daulat Press.

Interview with Marzuki Rais the foundation's president FAHMINA Cirebon, on 14-15 September 2017.

Interview with Rojikoh member of the foundation FAHMINA Cirebon, on 12 September 2017.
Interview with Devida member of the foundation FAHMINA Cirebon, on 14 September 2017.

Karnavian, M., T. (2011). The "Soft Approach" Strategy in Coping With Islamist Terrorism in Indonesia. Malakah, Jakarta.

Kafid, N. (2016). Dari Islamisme ke "Premanisme" Pergeseran Orientasi Gerakan Kelompok Islam Radikal di Era Desentralisasi Demokrasi, Masyarakat: Jurnal Sosiologi, Vol. 21, No. 1 : 57-79, LabSosio, Pusat kajian Sosiologi, Fakultas IImu Sosial dan Ilmu Politik (FISIP) Universitas Indonesia.

Muladi. (2011). "Kerja Sama Keamanan Regional dan Internasional dalam Pencegahan Terorisme Global". Ceramah PPSA XVII, 25 Mei.

Nurcholis, A. (2011). 10 Tahun ICRP: Melawan Kekerasan Atas Nama Agama, Jakarta: ICRP.

Purwawidada, F. (2014). Jaringan Baru Teroris Solo, Jakarta: Kepustakaan Populer Gramedia.

Qodir, Z. (2002). Syari ah Demokratik. Yogyakarta: Pustaka Pelajar.

Qodir, Z. (2014). Radikalisme Agama di Indonesia. Yogyakarta: Pustaka Pelajar.

Ruth, M., D. (2011). Terorisme: Kapankah Usai (Rekomendasi dan Catatan Kritis untuk UU pemberantasan Tindak Pidana Terorisme, Jakarta: Lazuardi Birru.

Zulkarnain, Fisher and Septayuda, T. (2016). The ISIS Movement and The Threat of Religious Radicalism in Indonesia, Mimbar: Jurnal Sosial Pembangunan, Vol. 32, No. 1, June, Bandung: P2U-LPPM Unisba, 